[3] Lie Fong S, Visser JA, Welt CK, et al. Serum anti-mullerian hormone levels in healthy females: a nomogram ranging from infancy to adulthood. J Clin Endocrinol Metab 2012;97:4650-5.

Acknowledgements: This study was funded by the Dutch Arthritis Foundation (Reumafonds). The pico AMH assays were generously provided by Ansh Labs (Houston, Texas, USA).

Furthermore, we would like to thank all patients and rheumatologists who contributed to the PARA study, as well as all researchers and laboratory workers who have worked on this project.

Disclosure of Interest: J. Brouwer: None declared, J. Laven: None declared, J. Hazes: None declared, N. Erler: None declared, J. Visser: None declared, R. Dolhain Grant/research support from: unrestricted research grant by UCB Pharma BV

DOI: 10.1136/annrheumdis-2017-eular.4270

\section{FRI0137 PRESENCE OF THYROID DISEASE IN RHEUMATOID ARTHRITIS PATIENTS IS PREDICTOR OF WORSE INITIAL TREATMENT RESPONSE: AN OBSERVATIONAL, COHORT STUDY}

A. Emamifar ${ }^{1}$, R. Hviid Larsen ${ }^{2}$, R. Asmussen Andreasen ${ }^{1}$, I.M. Jensen Hansen ${ }^{1,3} .{ }^{1}$ Rheumatology; ${ }^{2}$ Medicine, Svendborg Hospital, Odense University Hospital, Svendborg; ${ }^{3}$ DANBIO, Copenhagen, Denmark

Background: Rheumatoid Arthritis (RA) should be treated instantly to prevent further joint destruction. The first few months after treatment initiation are critical for long-term treatment outcome.[1]Patients with RA are at increased risk of thyroid disease with direct effect on initial treatment response.[2]

Objectives: To define the prevalence of thyroid disease among RA patients as well as to evaluate the correlation between presence of thyroid disease in RA patients and initial treatment response.

Methods: All RA patients who were registered in the local part of Danish Danbio registry were included in this study. Patients' demographic data, serology results including rheumatoid factor (RF) and anti-cyclic citrullinated peptide antibody (anti-ccp) as well as disease activity score in 28 joints-C-reactive protein (DAS28$\mathrm{CRP})$ at the time of diagnosis and after 4 months ( $\pm 1-2$ months) of treatment initiation were extracted. $\triangle$ DAS28 was calculated as follows: DAS28 at the time of diagnosis - DAS28 after 4 months ( $\pm 1-2$ months) of treatment initiation. Patients' electronic hospital records including laboratory results were reviewed to reveal if they had been diagnosed with thyroid disease.

Results: 1035 patients were included in the study (Table 1). Prevalence of thyroid disease was $11.8 \%(122 / 1035)$. Multiple linear regression analysis showed a negative correlation between $\triangle \mathrm{DAS} 28$ and presence of thyroid disease adjusted for age, gender, disease duration, RF, anti-ccp and DAS28 at the time of diagnosis (Regression coefficient (95\% Confidence Interval): $-0,157(-0.312$ to -0.002$)$, $\mathrm{P}=0.047$ ) (Table 2). RA patients with thyroid disease had significantly poorer initial response to RA treatment compared to patients with isolated RA after 4 months of treatment $(\mathrm{P}=0.002)$.

Table 1. Demographic and disease characteristics of the included $(\mathrm{N}=1035)$ patients

\begin{tabular}{|c|c|c|c|c|c|}
\hline \multicolumn{3}{|l|}{ Age (years), Mean \pm SD: } & \multicolumn{2}{|c|}{$67,1 \pm 14,5$} & \\
\hline \multicolumn{3}{|l|}{ Gender (\%) Female } & \multicolumn{2}{|c|}{$656(63.4 \%)$} & \\
\hline \multicolumn{3}{|c|}{ DAS28 at time of diagnosis, Mean \pm SD: } & \multicolumn{2}{|c|}{$4.5 \pm 0.9$} & \\
\hline \multicolumn{3}{|c|}{ DAS28 after 4 months of treatment, Mean \pm SD: } & \multicolumn{2}{|c|}{$3.1 \pm 0.8$} & \\
\hline \multicolumn{3}{|l|}{$\triangle \mathrm{DAS} 28$, Mean \pm SD: } & \multicolumn{2}{|c|}{$1.4 \pm 1.0$} & \\
\hline IgM Rheumatoid Factor (\%) P & itive & & \multirow{2}{*}{\multicolumn{2}{|c|}{$\begin{array}{l}607(58.6 \%) \\
532(51.4 \%)\end{array}$}} & \\
\hline \multicolumn{3}{|c|}{ Anti-ccp (\%) Positive } & & $4 \%)$ & \\
\hline \multirow[t]{2}{*}{ Variables } & \multirow[t]{2}{*}{ Coefficient } & \multirow[t]{2}{*}{ t-stat } & \multicolumn{2}{|c|}{ Confidence Interval } & \multirow[t]{2}{*}{$P$ value } \\
\hline & & & Lower $95 \%$ & Upper $95 \%$ & \\
\hline Age & 0,002 & 1.427 & -0.001 & 0.006 & 0.154 \\
\hline Male gender & 0,056 & 1.051 & -0.049 & 0.161 & 0.293 \\
\hline disease duration & $-0,003$ & -1.093 & -0.009 & 0.002 & 0.275 \\
\hline Rheumatoid Factor positivity & 0,010 & 0.159 & -0.118 & 0.139 & 0.873 \\
\hline Anti-ccp positivity & $-0,030$ & -0.456 & -0.158 & 0.098 & 0.649 \\
\hline DAS28 at diagnosis & 0,717 & 26.173 & 0.664 & 0.771 & $>0.001$ \\
\hline Presence of Thyroid Disease & $-0,157$ & -1.988 & -0.312 & -0.002 & 0.047 \\
\hline
\end{tabular}

Conclusions: Presence of thyroid disease in RA patients worsens initial treatment response and is suggestive of poor long-term prognosis. The authors propose routine measurement of serum thyroid stimulating hormone (TSH) in all RA patients at the time of diagnosis and with yearly interval.

References:

[1] Smolen JS, Aletaha D, Mclnnes IB. Rheumatoid arthritis. Lancet 2016; 388:2023-2038. doi: 10.1016/S0140-6736(16)30173-8.

[2] Joshi P, Agarwal A, Vyas S, et al. Prevalence of hypothyroidism in rheumatoid arthritis and its correlation with disease activity. Trop Doct 2017;47:6-10.

Acknowledgements: We thank Mrs. Maryam Mousavi for her contribution to data collection.

Disclosure of Interest: None declared

DOI: 10.1136/annrheumdis-2017-eular.3271

\section{FRI0138 LUNG INVOLVEMENT IN RHEUMATOID ARTHRITIS - A PORTUGUESE REALITY}

A.C. Duarte, S. Sousa, A. Cordeiro, M.J. Santos, J. Canas da Silva. Rheumatology, Hospital Garcia de Orta, Almada, Portugal

Background: Rheumatoid arthritis (RA) is associated with a wide range of extra-articular manifestations. Non-cardiac thoracic manifestations occur in approximately $5-20 \%$ and can affect the pleura, pulmonary parenchyma, airways and vasculature ${ }^{1}$. Besides, patients can also experience drug-induced pulmonary disease related to RA medication ${ }^{2}$.

Objectives: To characterize lung involvement and factors associated with lung disease in a cohort of RA patients.

Methods: Retrospective analysis of RA patients followed in our Rheumatology department. Lung involvement was defined by the presence of imagiologi$\mathrm{cal} /$ histopathological alterations described in the spectrum of rheumatoid arthritisassociated lung disease in either symptomatic or asymptomatic patients. Logistic regression analysis was used to evaluate demographic and clinical features independently associated with lung disease.

Results: In total, 532 RA patients were analysed, 400 females, mean age of 63.6 $( \pm 13.8)$ years and mean disease duration of $11.8( \pm 9.5)$ years. Rheumatoid factor (RF) was positive in $69 \%$ and anti-cyclic citrullinated peptide antibodies (ACPA) in $60 \% ; 8.8 \%$ were current smokers and $7.5 \%$ past smokers. Methotrexate (MTX) was the most prescribed synthetic DMARD (85.9\%) and biologics were used in $32.3 \%$ of patients.

Lung involvement was documented in 38 patients $(7.1 \%$; $95 \% \mathrm{Cl} 5.2 \%>9.7 \%)$. The specific types of lung disease are presented in figure 1 . The mean interval be tween articular and pulmonary symptoms was 6.1 ( \pm 6.4 ) years, with only 1 patient having lung involvement diagnosed prior to joint manifestations. Most patients were female (73.7\%), 78.9\% RF positive, $68.4 \%$ ACPA positive and $29 \%$ current/previous smokers. Secondary Sjögren's Syndrome was present in 5 patients. Eighteen (47\%) patients were medicated with MTX, 16 of them initiated therapy before developing respiratory symptoms and $10(26.5 \%)$ with biologics (4 with TNF antagonists, 3 with tocilizumab, 2 with rituximab and 1 with abatacept). Most patients $(92.1 \%)$ had abnormal chest $x$-rays, but only $47.4 \%$ were symptomatic. Pulmonary function tests (PFT) were abnormal in $31.6 \%$ of patients and $47.4 \%$ had diffusing capacity for carbon monoxide (DLCO) less than $75 \%$ predicted 7 had no DLCO estimated). Respiratory insufficiency was present in 7 (18.4\%) patients. In multivariate logistic regression analysis, current MTX use (OR: 2.1 [1.02-4.33]), RF positivity (OR: 3.48 [1.18-10.25]) and older age (OR: 1.03 [1.00-1.06)] were independently associated with lung involvement.

\begin{tabular}{|c|c|c|c|c|c|}
\hline $\begin{array}{l}\text { Type of lung } \\
\text { involvement }\end{array}$ & UIP $(n=10)$ & NSIP $(n=8)$ & $\begin{array}{c}\text { Bronchiectasis } \\
(n=16)\end{array}$ & $\begin{array}{c}\text { Follicular } \\
\text { bronchiolitis }(n=1)\end{array}$ & $\begin{array}{c}\text { Pleural } \\
\text { involvement }(n=3)\end{array}$ \\
\hline Female & 7 & 6 & 14 & 1 & 0 \\
\hline RF positive & 8 & 7 (1 missing) & 12 (1 missing) & 1 & 2 (1 missing) \\
\hline Smoking & 4 (1 missing) & 3 & 3 & 0 & 1 \\
\hline \multirow[t]{3}{*}{ PFT } & 4 normal & 5 normal & 9 normal & \multirow[t]{3}{*}{1 normal } & \multirow[t]{3}{*}{3 normal } \\
\hline & 3 restrictive & 1 restrictive & 4 restrictive & & \\
\hline & 1 obstructive & $\begin{array}{c}1 \text { restrictive } \\
+ \text { obstructive }\end{array}$ & 2 obstructive & & \\
\hline DLCO $<75 \%$ & 7 & 3 (2 missing) & 7 (3 missing) & 0 & 2 \\
\hline
\end{tabular}

Figure 1 - Specific types of lung involvement and its characteristics

Conclusions: Lung involvement was present in $7.3 \%$ of our cohort and was diagnosed in average 6.1 years after the first joint manifestations. RF positivity, older age and current MTX use are associated with lung disease.

As most patients remain asymptomatic, lung involvement is probably underdiagnosed in RA patients. Besides, in clinical practice exams that can detect preclinical disease, such as high-resolution chest computed tomography, are usually reserved for symptomatic patients or with an abnormal chest x-ray.

\section{References:}

[1] Chansakul T, Dellaripa, Doyle TJ, Madan R. Intra-thoracic rheumatoid arthritis: imaging spectrum and treatment related complications. Eur J Radiol. 2015 October; 84(10): 1981-1991.

[2] Megan Shaw, Bridget F. Collins, Lawrence A. Ho and Ganesh Raghu. Rheumatoid arthritis-associated lung disease. Eur Respir Rev 2015; 24: 1-16

Disclosure of Interest: None declared

DOI: 10.1136/annrheumdis-2017-eular.4513

\section{FRI0139 PREVALENCE OF HYPERPARATHYROIDISM IS HIGHER AMONG RHEUMATOID ARTHRITIS PATIENTS COMPARED TO THE GENERAL POPULATION: AN OBSERVATIONAL, COHORT STUDY}

A. Emamifar $^{1}$, L. Stilgren ${ }^{2}$, R. Hviid Larsen ${ }^{3}$, R. Asmussen Andreasen ${ }^{1}$, I.M. Jensen Hansen 1,4 . ${ }^{1}$ Rheumatology; ${ }^{2}$ Endocrinology; ${ }^{3}$ Medicine, Svendborg Hospital, Odense University Hospital, Svendborg; ${ }^{4}$ DANBIO, Copenhagen, Denmark

Background: Patients with Rheumatoid Arthritis (RA) are at increased risk of different comorbidities which may affect long-term prognosis.[1] Primary hyperparathyroidism (PHP) is a metabolic disorder of one or more of the parathyroid glands with a prevalence of 1-7 per 1000 adults.[2] 